doc. dr. sc. Ivana Dropulić

Ekonomski fakultet, Sveučilište u Splitu, Split, Republika Hrvatska ivana.dropulic@efst.hr

\title{
UTJECAJ INFORMACIJSKIH TEHNOLOGIJA NA UPRAVLJAČKO RAČUNOVODSTVO
}

Primljen: 15. srpnja 2019.

Prihvaćen: 21. listopad 2019.

Pregledni rad

\section{Sažetak}

Temeljem pregleda prethodnih istraživanja odnosa između informacijskih tehnologija (IT) $i$ upravljačkog računovodstva može se zaključiti da postoji određeni jaz u razumijevanju i poznavanju navedenog odnosa. S obzirom da u literaturi postoji nedostatak jasno identificiranih nastalih promjena $u$ upravljačkom računovodstvu pod utjecajem IT, svrha ovoga istraživanja je pružiti pregled i ocjenu istraživanja utjecaja IT na upravljačko računovodstvo kako bi se omogućili temelji za bolje razumijevanje navedenog odnosa, kako u znanstvenom području tako i u praksi.

Rad pruža sveobuhvatan pregled istraživanja utjecaja IT na praksu upravljačkog računovodstva te ulogu i zadaću upravljačkog računovođe u organizaciji kroz proteklih 15 godina. Prema rezultatima istraživanja može se zaključiti da IT imaju značajnu ulogu u praksi upravljačkog računovodstva, posebno u domeni internog izvještavanja, planiranja te primjene naprednih tehnika upravljačkog računovodstva kao i na ulogo i zadaću upravljačkog računovođe u organizaciji. Upravljačke računovođe manje obavljaju rutinske poslove, a više su uključeni $u$ proces analize, dok su outputi upravljačkog računovodstva pod utjecajem IT precizniji, točniji i frekventniji.

Ključne riječi: informacijske tehnologije, sustavi planiranja resursa poduzeća (ERP), upravljačko računovodstvo

JEL: M41, M49

\section{UVOD}

Tijekom posljednjih nekoliko desetljeća, zbog izraženog tehnološkog napretka, informacijske tehnologije (engl. Information Technology - IT) bilježe progresivan i intenzivan razvoj. Informacijske tehnologije predstavljaju značajnu podršku 
poslovnim procesima $\mathrm{u}$ organizaciji te imaju ključnu ulogu $\mathrm{u}$ upravljačkom računovodstvu i menadžerskoj kontroli (Granlund, 2007). Jedan od preduvjeta uspješnog poslovanja organizacije jest potpora integriranog informacijskog sustava (IIS) koji predstavlja informacijski sustav u kojemu su sve aktivnosti nad podacima i informacijama potpuno integrirane u sve poslovne procese (Garača, 2004, 204). Integrirani informacijski sustavi, kao što je sustav planiranja resursa poduzeća (engl. Enterprise Resource Planning - ERP), postali su neizostavan alat u upravljačkom računovodstvu i jedan od ključnih pokretača promjena u području upravljačkog računovodstva. Implementirani ERP sustavi pokreću promjene u organizaciji i njenom poslovanju pa tako i promjene u upravljačkom računovodstvu i zadaćama upravljačkog računovođe. Odnos između IT i upravljačkog računovodstva može se promatrati dvosmjerno budući da IT mogu utjecati na upravljačko računovodstvo, ali i upravljačko računovodstvo može biti pokretač različitih rješenja IT. S obzirom na navedeno, neka od prethodnih istraživanja odnosa između IT i upravljačkog računovodstva su istraživala utjecaj IT na upravljačko računovodstvo dok su druga istraživala kako upravljačko računovodstvo i menadžerska kontrola oblikuju rješenja IT (Granlund i Mouritsen, 2003, Granlund, 2007, Maraghini, 2010).

Ovo istraživanje je fokusirano na utjecaj IT na upravljačko računovodstvo, odnosno, daje uvid u promjene prakse upravljačkog računovodstva i rada upravljačkog računovođe kao rezultata primjene IT. Nakon implementacije IT očekuje se da će doći do promjena u praksi upravljačkog računovodstva u segmentu prikupljanja podataka, internog izvještavanja, poslovnog planiranja te primjene novih naprednih tehnika upravljačkog računovodstva kao što su ABC metoda (engl. Activity-Based Costing), BSC model (engl. Balanced Scorecard) i sl. Iako se je povećao broj studija u ovom području istraživanja, odnos između IT i upravljačkog računovodstva je još uvijek nedovoljno istražen, i s teorijskog i s praktičnog aspekta, a samim time ne postoji ni konsenzus među istraživačima o navedenoj vezi.

S obzirom na prethodno navedeno ovo istraživanje ima sljedeće ciljeve:

- Pružiti sveobuhvatan pregled prethodnih empirijskih istraživanja odnosa između IT i upravljačkog računovodstva u proteklih 15 godina kako bi se identificirale temeljne karakteristike navedenog odnosa.

- Pružiti smjernice za buduća istraživanja ove tematike kako bi se omogućili temelji za bolje razumijevanje navedenog odnosa, kako u znanstvenom području tako i u praksi.

Rad se sastoji od četiri poglavlja uključujući uvod i zaključak. U uvodnom dijelu se objašnjava uloga i značaj IT, odnosno njihov utjecaj na upravljačko računovodstvo i zadaće upravljačkog računovođe. U drugom dijelu se definiraju pojmovi informacijske tehnologije (IT), integrirani informacijski sustavi (IIS) i sustavi planiranja resursa poduzeća (ERP). Treći dio prikazuje pregled provedenih 
istraživanja utjecaja IT na upravljačko računovodstvo. Na kraju rada iznose se osnovni zaključci do kojih se došlo provedbom istraživanja te preporuke za daljnja istraživanja ove tematike.

\section{INFORMACIJSKE TEHNOLOGIJE (IT)}

Informacijske tehnologije (IT) su postale ključni nositelj računovodstvenih informacija $u$ današnjem globalnom društvu znanja, te jedan od najznačajnijih pokretača razvoja u upravljačkom računovodstvu (Granlund, 2007). Kako bi poboljšale poslovne performanse, te ostvarile konkurentsku prednost na lokalnom ali i međunarodnom tržištu, organizacije sve više implementiraju različite aspekte informacijskih tehnologija. Prema Milanović Glavan $(2014,39)$ informacijske tehnologije omogućavaju "praćenje poslovnih aktivnosti, kontinuirano prikupljanje podataka o uspješnosti poslovanja, usporedbu povijesnih, ostvarenih i ciljanih vrijednosti prikupljenih podataka, izvlačenje informacija iz primarnih podataka o novim trendovima ili anomalijama u poslovanju te dostavljanje dobivenih rezultata sudionicima poslovanja."

Kao odgovor na kontinuirano rastuće potrebe menadžmenta uslijed globalizacije tržišta, internacionalizacije poslovanja te intenzivnog razvoja komunikacijskih tehnologija javljaju se sustavi planiranja resursa poduzeća, ERP sustavi (Malinić i Todorović, 2012). Pomoću ERP sustava prikupljaju se i širom organizacije raspodjeljuju informacije čime se stvara podloge za kvalitetno donošenje poslovnih odluka. ERP je programsko rješenje koje obuhvaća cijeli model poslovanja organizacije, podržava i integrira rad svih službi i funkcija te povezuje sve interne i eksterne poslovne procese organizacije (Milanović Glavan, 2014). Pomoću ERP sustava se integriraju svi pojedini informatički sustavi organizacije u jedan cjeloviti sustav podijeljen u module, a koji koristi jedinstvenu bazu podataka što različitim odjelima unutar organizacije omogućuje učinkovitije dijeljenje informacija te vodi prema boljem planiranju i većoj produktivnosti. ERP sustavi podržavaju organizacijski sustav na operativnoj razini, pomažući u koordiniranju svih poslovnih procesa kako bi se postigla što veća učinkovitost u njihovu obavljanju, ali i na strateškoj razini gdje pružaju sve potrebne informacije za upravljanje sustavom i provedbu organizacijskih promjena, potrebnih za opstanak i razvoj organizacije. Glavna karakteristika ERP sustava, koja omogućuje ostvarili ova dva navedena cilja, je upravo integracija podataka (Belak i Ušljebrka, 2014).

Šimunović et al. (2013) su proveli istraživanje na uzorku od 30 malih do srednje velikih organizacija u RH kako bi razmotrili vezu između poslovnih i informacijskih aktivnosti $\mathrm{s}$ naglaskom na: stupanj znanja zaposlenika o ERP sustavima, njihovo povjerenje i odnos prema uvođenju ERP sustava, učinkovitost sustava u radnom okruženju, mogućnost reorganizacije proizvodnog procesa, ulaganje u poboljšanje sustava, integriranost sa svim odjelima u organizaciji i 
stupanj zadovoljstva korištenjem ERP sustava. Prema rezultatima istraživanja, kao glavne prednosti ERP sustava, ispitanici su naveli uštedu vremena i praćenje troškova, a kao glavne nedostatke inicijalne troškove te dugo razdoblje implementacije, integracija i testiranje.

Prema istraživanju tržišta ERP sustava iz 2016. godine (Panorama Consulting Solutions) utvrđeno je da je SAP najveći dobavljač na tržištu ERP sustava sa tržišnim udjelom od $19 \%$. Sljedeći grafikon prikazuje tržišne udjele dobavljača ERP sustava prema navedenom istraživanju.

Grafikon 1: Tržišni udio ERP dobavljača

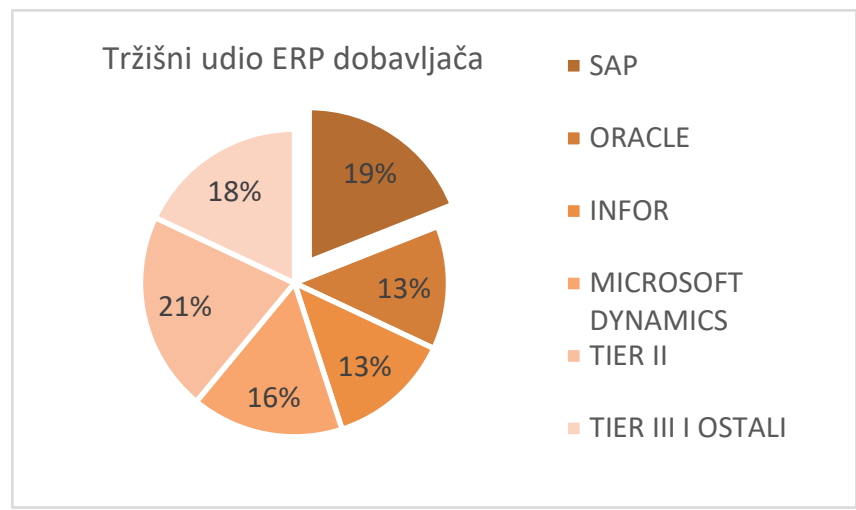

Izvor: Panorama Consulting Solutions: CLASH OF THE TITANS 2017

https://www.panorama-consulting.com/wp-content/uploads/2017/10/White-Paper-Clash-ofthe-Titans-2017.pdf

\section{PREGLED PRETHODIH ISTRAŽIVANJA}

Tablica 1 prikazuje sažetak prethodnih istraživanja utjecaja IT na upravljačko računovodstvo iz koje se vidi godina, autor/i, zemlja i uzorak na kojem je provedeno istraživanje.

Tablica 1: Prikaz istraživanja utjecaja IT na upravljačko računovodstvo

\begin{tabular}{|l|l|l|l|}
\hline Godina & Autor & Zemlja & Uzorak \\
\hline 2005 & Spathis i Ananiadis & Grčka & $\begin{array}{l}\text { studija slučaja (javno } \\
\text { sveučilište u Grčkoj) }\end{array}$ \\
\hline 2006 & El-Sayed & Egipat & $\begin{array}{l}\text { studija slučaja (Sun Steel } \\
\text { kompanija član Sun Group) }\end{array}$ \\
\hline 2006 & $\begin{array}{l}\text { Rikhardsson i } \\
\text { Kræmmergaard }\end{array}$ & Danska & 6 \\
\hline 2006 & Rom i Rohde & Danska & 349 \\
\hline 2006 & Spathis & Grčka & 73 \\
\hline 2007 & Kholeif, Abdel-Kader i & Egipat & studija slučaja \\
\hline
\end{tabular}




\begin{tabular}{|l|l|l|l|}
\hline & Sherer & & $\begin{array}{l}\text { (AML-kompanija u državnom } \\
\text { vlasništvu) }\end{array}$ \\
\hline 2008 & Jackling i Spraakman & Austrija & 35 \\
\hline 2008 & Jack i Kholeif & Egipat & $\begin{array}{l}\text { studija slučaja (IMC - } \\
\text { Industrial Modernisation } \\
\text { Centre) }\end{array}$ \\
\hline 2008 & O’ Mahony i Doran & - & studija slučaja \\
\hline 2009 & Jean-Baptiste & - & 212 \\
\hline 2010 & $\begin{array}{l}\text { Sangster, Leech i } \\
\text { Grabski }\end{array}$ & Uaraghini & 62 \\
\hline 2011 & $\begin{array}{l}\text { Kallunki, Laitinen i } \\
\text { Silvola }\end{array}$ & Finska & 96 \\
\hline 2011 & Kanellou i Spathis & Grčka & 193 \\
\hline 2011 & $\begin{array}{l}\text { De Silva, Gunawardana i } \\
\text { Silva }\end{array}$ & Sri Lanka & 32 \\
\hline 2012 & Malinić i Todorović & $\begin{array}{l}\text { Republika } \\
\text { Srbija }\end{array}$ & 9 \\
\hline 2013 & Al-Eqab i Adel & Jordan & 174 \\
\hline 2018 & $\begin{array}{l}\text { Dwi May Adi Indra, } \\
\text { Noorlailie, Isnalita }\end{array}$ & - & 60 \\
\hline 2018 & $\begin{array}{l}\text { Goumas, Charamis i } \\
\text { Tabouratzi }\end{array}$ & Grčka & 182 \\
\hline 2018 & Šimić & $\begin{array}{l}\text { Republika } \\
\text { Hrvatska }\end{array}$ & $\begin{array}{l}\text { studija slučaja (Dm-drogerie } \\
\text { markt d.o.o.) }\end{array}$ \\
\hline 2019 & Pervan i Dropulić & $\begin{array}{l}\text { Republika } \\
\text { Hrvatska }\end{array}$ & 108 \\
\hline
\end{tabular}

Spathis i Ananiadis (2005) su proveli studiju slučaja na velikom javnom sveučilištu u Grčkoj kako bi istražili utjecaj koji proizlazi iz novoga ERP sustava na računovodstvene informacije $\mathrm{i}$ menadžment temeljeno na percipiranoj koristi prema očekivanjima i percepcijama korisnika. Rezultati studije pokazuju da je godinu dana nakon implementacije percepcija korisnika više pozitivna u usporedbi sa njihovim očekivanjima u periodi prije implementacije. Također, postoje brojne prednosti koje proizlaze iz novoga ERP sustava posebno $u$ odnosu na računovodstvene informacije i menadžment. Novi ERP sustav značajno doprinosi fleksibilnosti u pružanju informacija, učinkovitom praćenju i iskorištavanju sveučilišne imovine i toku prihoda/rashoda te poboljšanom donošenju odluka.

Na primjeru studije slučaja kompanije Sun Steel koja je član Sun Group provedeno je istraživanje o utjecaju ERP sustava na ekspertizu računovođa, odnosno, na pokušaj računovođa u Sun Steel-u da redefiniraju i ponovo se pozicioniraju u odnosu na ERP sustave (El-Sayed, 2006). Studija ukazuje na činjenicu da 
računovođe pojavu ERP sustav ne promatraju kao prijetnju već kao priliku gdje su njihove vještine i računovodstveno znanje predstavljeni kao važne karike za ispravno funkcioniranje ovih tehnologija. Nadalje, može se reći da računovođe i tehnologije, kao što su ERP sustavi, imaju sve više isprepleten odnos, odnosno, niti se računovođe niti ERP sustavi mogu smatrati pasivnim sudionicima nego ih treba promatrati kako se međusobno redefiniraju u odnosu jedni na druge.

Istraživanje Rikhardsson i Kræmmergaard (2006) prikazuje rezultate eksplorativne studije o učincima implementacije i korištenja ERP sustava na primjeru šest velikih danskih tvrtki, a koji je dio većeg ERP studijskog programa na Aarhus School of Business. Prema ključnim rezultatima istraživanja učinci implementacije i korištenja ERP sustava su rijetko u potpunosti predvidljivi od strane menadžmenta te uvelike utječe na vrijednosti, kulturu, ponašanje, procese i postupke drugih aktera $u$ organizaciji. S obzirom na složenost, veličinu i organiziranost ERP sustava, može se reći da proces implementacije nikada ne završava, a ERP sustavi postaju značajna varijabla za buduće poslovanje organizacije.

Rom i Rohde (2006) su proveli istraživanje na uzorku od 349 kompanija u Danskoj kako bi utvrdili u kojoj mjeri integrirani informacijski sustavi, kao što su ERP sustavi i SEM sustavi (engl. Strategic enterprise management systems), utječu na sposobnost rješavanja različitih zadataka upravljačkog računovodstva. Prema dobivenim rezultatima, ERP sustavi (sustavi usmjereni na transakcije) podržavaju prikupljanje podataka i organizacijsku širinu upravljačkog računovodstva bolje od SEM sustava dok SEM sustavi (sustavi usmjereni na analizu) bolje podržavaju izvještavanje $\mathrm{i}$ analizu kao i moderne tehnike upravljačkog računovodstva koje uključuju korištenje ne financijskih podataka. S obzirom na navedeno, može se zaključiti da različite zadatke upravljačkog računovodstva podržavaju različiti dijelovi integriranog informacijskog sustava.

Prema istraživanju Spathis (2006) na uzorku od 73 kompanije u Grčkoj utvrđeno je da su najznačajnije koristi od uvođenja ERP sustava povećana fleksibilnost u generiranju informacija, povećana integracija aplikacija, poboljšana kvaliteta financijskih izvještaja, smanjenje vremena za izdavanje računovodstvenih izvještaja i poboljšanje procesa donošenja odluka. Glavne računovodstvene koristi od ERP sustava su usmjerene na organizacijsku i operativnu dimenziju.

Detaljnu analizu studije slučaja, kako bi interpretirali i razumjeli neuspjeh implementacije tehnologije ERP sustava u egipatskoj državnoj kompaniji AML, napravili su Kholeif, Abdel-Kader i Sherer (2007). Neuspjeh ERP sustava objašnjava se kao rezultat uzajamnog djelovanja institucionalnih računovodstvenih praksi, sukobljenih institucija, odnosa moći i tržišnih snaga. Kao eksplicitni razlog neuspjeha ERP sustava navedena je nemogućnost ERP sustava da ispuni osnovne računovodstvene zahtjeve kontrolnih tijela (engl. The central agency for accountability). Osim toga, utvrđeno je da u visoko reguliranom ekonomskom i 
političkom okruženju, tržišni pritisci i konkurencija također sprečavaju usvajanje novih, navodno učinkovitijih računovodstvenih sustava.

Jackling i Spraakman (2008) su proveli istraživanje na uzorku od 35 kompanija u Australiji koje imaju implementiran ERP sustav najmanje 10 godina kako bi utvrdili utjecaj ERP sustava na proces upravljačkog računovodstva s naglaskom na utjecaj ERP sustava na kapitalni budžet, kao specifičnu i važnu tehniku upravljačkog računovodstva. ERP sustavi i informatizacija mijenjaju praksu upravljačkog računovodstva pa tako i kapitalnog budžetiranja, međutim u ovoj fazi, utjecaj na tehnike kapitalnog budžetiranja, iako važan, je ograničen i vjerojatno preliminarni.

Istraživanje koje su proveli Jack i Kholeif (2008) je još jedno istraživanje koje je provedeno na studiji slučaja i to organizacije IMC (engl. Industrial Modernisation Centre) koja je financirana od strane EU i Egipatske vlade. ERP sustav BAAN uveden je u IMC kako bi se prevladale slabosti postojećeg sustava i omogućilo samo širenje organizacije. Rezultati studije slučaja ukazuju na činjenicu da se ERP sustavi, kao jedna od najnovijih tehnoloških promjena, intenzivno koriste $\mathrm{u}$ državnim tijelima angloameričkim zemljama dok ih još uvijek nije lako integrirati u slična tijela zemalja u razvoju. Nadalje, u slučaju IMC, implementirani ERP sustav nije promijenio korištenje računovodstvenog sustava i prakse te je uloga računovođe svedena na osobu koja čuva podatke i pruža informacije za one koji upravljaju i kontroliraju organizaciju.

Glavni cilj istraživanja O' Mahony i Doran (2008) je uloga ERP sustava u organizaciji te utjecaj koji ERP sustavi imaju na ulogu upravljačkog računovođe koja se razvija od tradicionalne u dinamičnije uključivanje u poslovanje. Istraživanje je provedeno na studiji slučaja multinacionalne podružnice u kojoj računovodstvo ima značajnu ulogu te koja je uložila značajna sredstva u informacijske sustave. Prema procjeni ispitanika utvrđeno je da upravljačke računovođe troše do $30 \%$ svoga vremena koristeći ERP sustave te su nove tehnike integrirale nove uloge i odgovornosti u zadaće upravljačkog računovođe, odnosno, u središte pozornosti dolaze upravljačke računovođe koji postaju prepoznatljivi kao agenti promjene u organizaciji. Kao glavne prednosti ERP sustava navode se poboljšana učinkovitost, pravovremenosti, globalno integrirani sustavi, ušteda vremena i funkcionalnost, dok su kao nedostaci navedeni prilagođavanje potrebama organizacije, opseg iskorištenja mogućnosti ERP sustav i manipulacija informacijama.

Jean-Baptiste (2009) je proveo istraživanje na uzorku od 212 profesionalnih računovođa koji imaju iskustvo sa ERP sustavima, a članovi su IMA (engl. Institute Of Management Accountants) kako bi istražio ulogu i utjecaj računovođa u fazi implementacije i post-implementacije ERP sustava. Rezultati studije jasno ukazuju da računovođe igraju ključnu ulogu u implementaciji i održavanju ERP 
sustava te da postoji pozitivna veza između uspješne implementacije ERP sastava i sudjelovanja računovođe $\mathrm{u}$ procesu implementacije ERP sustava. Također, računovođe koje posjeduju tehničke ili IT vještine uz financijsku stručnost češće sudjeluju u timovima za implementaciju ERP sustava.

Prema istraživanju Sangster, Leech i Grabski (2009) provedenom na uzorku od 62 organizacije u UK utvrđeno je da je SAP dominantan ERP sustav te da implementacija ERP sustava rezultira promjenama u zadaćama $\mathrm{i}$ odgovornostima upravljačkog računovođe, međutim bez značajnog utjecaja na upravljačko računovodstvo općenito. Također, ERP sustavi imaju pozitivan utjecaj na operativne faktore kao što su planiranje, produktivnost, dostava na vrijeme, donošenje odluka s tim da je najveće poboljšanje u kvaliteti informacija/podataka. Što se tiče uspješnosti implementacije ERP sustava utvrđeno je da se ERP sustav percipira uspješnijim ako podržava osnovne poslovne procese i pruža pravovremene informacije što rezultira značajnim smanjenjem vremena za upravljačke računovođe u obavljanju tradicionalnih zadataka.

U Italiji, na primjeru studije slučaja društva I.V.V. - Industria Vetraria Valdarnese provedeno je istraživanje o utjecaju implementacije nove IT na proces promjene $u$ menadžerskoj kontroli (Maraghini, 2010). Prema rezultatima navedene studije slučaja utvrđeno je da sa implementacijom IT nisu uvedene nove napredne tehnike upravljačkog računovodstva kao što su ABC metoda i BSC model niti je došlo do kompjuterizacije zadataka menadžerske kontrole. Međutim, novi sustav pruža mnogo više informacija koje su sada pouzdanije, više integrirane i pravovremene. Iako se sada rutinski poslovi kontrolora ili upravljačkog računovođe obavljaju automatizmom pomoću novog sustava oni i dalje ostaju pod nadležnosti iste osobe čime se njihov obujam ne smanjuje već se povećava sa dodatnim drugim obvezama i odgovornostima.

Kallunki, Laitinen i Silvola (2011) su istražili zajedničku ulogu ERP sustava i sustava menadžerske kontrole u poboljšanju performansi poslovanja. Prema rezultatima istraživanja, provedenog na uzorku od 70 poslovnih jedinica u Finskoj, može se zaključiti da korištenje ERP sustava rezultira boljim dugoročnim performansama organizacije, te da više formalni u odnosu na neformalne oblike menadžerskih kontrola pomažu organizacijama u ostvarenju zadanih, ciljnih performansi. Drugim riječima, značajna povezanost između ERP sustava i budućih nefinancijskih performansi se postiže posredovanjem varijable formalne menadžerske kontrole, odnosno, formalne menadžerske kontrole posreduju u pozitivnom utjecaju ERP sustava na nefinancijske performanse.

Najviše ocjenjene percipirane računovodstvene koristi postignute nakon implementacije ERP sustava su IT računovodstvene koristi, organizacijske računovodstvene koristi i operativne računovodstvene koristi u vidu vremena (Kanellou i Spathis, 2011). Ovakvi rezultati potvrđuju činjenicu da se podaci 
prikupljaju i obrađuju lakše i brže uz pomoć ERP sustava te ukazuju na značajno smanjenje vremena potrebnog za pripremu i izradu izvještaja. Iako implementacija ERP sustava rezultira mnogobrojnim računovodstvenim koristima ipak nema značajan utjecaj na smanjenje broja zaposlenika u odjelu računovodstva. Također, prema istom istraživanju, nema statistički značajne razlike što se tiče mjerenja računovodstvenih koristi između računovođa i IT osoblja dok su računovođe zadovoljnije radom ERP sustava u odnosu na IT osoblje.

De Silva, Gunawardana i Silva (2011) istražili su kako podrška dobavljača ERP sustava i obuka ERP korisnika utječe na korištenje ERP sustava kroz pet funkcija upravljačkog računovodstva i to: kapitalni plan, budžetiranje, ABC metoda, prognoziranje i operativno izvještavanje. Istraživanje je provedeno na uzorku od 32 organizacije na Sri Lanki te je utvrđeno da ERP sustavi poboljšavaju kvalitetu procesa upravljačkog računovodstva te da obuka i podrška dobavljača utječe na korištenje ERP sustava u upravljačkom računovodstvu. ERP sustavi poboljšavaju kapacitet i točnost podataka korištenih za kapitalno planiranje i budžetiranje, a operativno izvještavanje i prognoziranje je više dugoročno usmjereno i pouzdanije $\mathrm{s}$ obzirom na pravovremene $\mathrm{i}$ točne podatke bez dupliciranja, nejasnoća $\mathrm{i}$ pogrešaka.

Prema istraživanju Malinić i Todorović (2012), na uzorku od 9 organizacija u Republici Srbiji koje koriste SAP kao vodeći ERP sustav, utvrđeno je da ERP sustavi značajno utječu na upravljačko računovodstvo, ali i na ulogu i zadatke upravljačkog računovođe. Odnosno, utvrđeno je da SAP skraćuje vrijeme potrebno za tradicionalne zadatke upravljačkog računovodstva dok istovremeno povećava vrijeme potrebno za aktivnosti analize podataka, mjerenja performansi i strateškog izvještavanja. Također, utvrđeno je da dolazi do značajne promjene u ulozi upravljačkih računovođa organizacije.

Prema istraživanju Al-Eqab i Adel (2013) provedenog na uzorku od 174 kompanije koje kotiraju na jordanskoj burzi utvrđena je značajna i pozitivna veza između četiri dimenzije IT softiciranosti (tehnološka, informacijska, funkcionalna i upravljačka) i karakteristika računovodstvenih informacija (opseg, agregacija, integracija i pravovremenost). Karakteristike računovodstvenih informacija mogu se postići ulaganjem ne samo u tehnološku dimenziju IT, nego što je još važnije, informacijsku, funkcionalnu i upravljačku dimenziju IT.

ERP sustav značajno utječe na relevantnost računovodstvenih informacija koje se sastaje od tri varijable (prediktivna, pravovremena i vrijednost povratne informacije) i performanse organizacije (Dwi May Adi Indra, Noorlailie i Isnalita, 2018). Istraživanje je provedeno na uzorku od 60 organizacija, 30 koje imaju i 30 koje nemaju implementiran ERP sustav, te je utvrđeno značajna razlika između organizacija koje imaju i onih koje nemaju implementirane ERP sustave u vidu relevantnih vrijednosti računovodstvenih informacija. Organizacije sa 
implantiranim ERP sustavim imaju širi opseg informacija te brže obrađuju podatke za potrebe donošenja poslovnih odluka, ali imaju i veću vrijednost u vidu povratnih informacija za poboljšanje performansi poslovanja u budućnosti.

Goumas, Charamis i Tabouratzi (2018) su proveli istraživanje na uzorku od 182 srednja i mala poduzeća proizvodne djelatnosti u Grčkoj kako bi istražili računovodstvene koristi (IT računovodstvene koristi, menadžerske računovodstvene koristi, operativne računovodstvene koristi u vidu troškova, operativne računovodstvene koristi $u$ vidu vremena, organizacijske računovodstvene koristi) od implementacije ERP sustava. Prema rezultatima provedenog istraživanja utvrđeno je da organizacijske i IT računovodstvene koristi ostvaruju bolje rezultate od ostalih kategorija $\mathrm{i}$ to $\mathrm{u}$ vidu poboljšanja kvalitete izvještavanja i redukcije potrebnog vremena za unos transakcija i evidencije platnog prometa.

U Hrvatskoj, na primjeru studije slučaja društva Dm-drogerie markt d.o.o., provedeno je istraživanje o utjecaju SAP ERP 6.0 integriranog informacijskog sustava na poslovanje društva, upravljačko računovodstvo i ulogu upravljačkog računovođe (Šimić, 2018). Rezultati studije slučaja ukazuju na značajan utjecaj ERP sustava na ulogu upravljačkog računovođe i to na način da se je vrijeme utrošeno na prikupljanje i analizu podataka značajno smanjilo dok se je $s$ druge strane, mjerenje performansi i benchmarking te uključenost $u$ donošenje poslovnih odluka povećalo.

Prema istraživanju Pervan i Dropulić (2019), provedenom na uzorku od 108 društava u RH, utvrđena je značajna i pozitivna veza između analitičkih sposobnosti IIS i upravljačkog računovodstva, odnosno implementirani informacijski sustavi značajno utječu na: interno izvještavanje menadžera, izradu i kontrolu financijskog plana, implementaciju modernih tehnika upravljačkog računovodstva, te na zaposlenike u računovodstvu, kontrolingu ili financijama koji sudjeluju u internom izvještavanju.

\section{ZAKLJUČAK}

Informacijske tehnologije (IT) i upravljačko računovodstvo su sastavni dijelovi modernog poslovanja, a IT značajno utječu na upravljačko računovodstvo i računovodstvenu profesiju. IT su promijenile temelje načina na koji računovođe obavljaju svoje poslove, odnosno, omogućile su računovođama da generiraju pravovremena i točna izvješća, a tradicionalnu ulogu zamjene ulogom poslovnog savjetnika. Računovodstveni informacijski sustavi sada pored povijesnih i financijskih podataka uključuju i ne financijske podatke te podatke orijentirane prema budućnosti. Uloga i zadaća računovođe, kao i samog računovodstva, se sad 
promatra u mnogo širem smislu uključujući i poslovne procese i strateško upravljanje.

Međutim, unatoč činjenici da IT olakšavaju rad računovođama u određenim segmentima one također predstavlja izazov za računovođe u vidu povećanja odgovornosti i potrebnih kompetencija. Kompetentnost u području IT je jedan od krucijalnih faktora u ekonomiji znanja, a profesionalne računovođe moraju posjedovati dovoljno IT znanja i vještina zbog sve prisutne upotrebe i nužnosti IT u poslovnom svijetu (Gómez, 2017). U ovom novom poslovnom okruženju kojeg karakterizira izražena konkurentnost, informatizacija i globalizacija upravljačke računovođe moraju steći široko znanje o poslovanju i dodati vrijednost organizaciji te postati strateški menadžer. Upravljačke računovođe i upravljačko računovodstvo se pomiču u središte pozornosti i postaju sastavni dio menadžmenta (O' Mahony i Doran, 2008). Uloga upravljačkog računovođe u organizacijama, u narednim godinama, će samo dobivati na sve većem značaju, pogotovo zbog niza globalnih sila koje utječu na praksu upravljačkog računovodstva uključujući digitalizaciju i intelektualni kapital (Bhimani et al., 2018, 25).

Prema rezultatima prethodnih istraživanja utjecaja ERP sustava na upravljačko računovodstvo i upravljačke računovođe može se zaključiti da ne postoji konsenzus među istraživačima o načinu promjene zadataka upravljačkog računovodstva pod utjecajem ERP sustava. Ipak, navedena istraživanja sugeriraju da će upravljačke računovođe vjerojatno manje obavljati rutinske poslove, a više će biti uključeni u proces analize, dok će outputi upravljačkog računovodstva biti precizniji, točniji i frekventniji. Buduća istraživanja ovoga područja trebala bi proučavati integrirane informacijske sustave u širem kontekstu obuhvaćajući sve integrirane sustave (ERP i specijalizirane samostalne aplikacije izvan ERP-a) u društvu budući da različiti dijelovi integriranog informacijskog sustava podržavaju različite zadatke upravljačkog računovodstva.

\section{LITERATURA}

1. Al-Eqab, M., Adel, D. (2013): The Impact of IT Sophistications on the Perceived Usefulness of Accounting Information Characteristics among Jordanian Listed Companies. International Journal of Business and Social Science, Vol. 4, No. 3, str. 145-155.

2. Belak, S., Ušljebrka, I. (2014): Uloga ERP sustava u promjeni poslovnih procesa, Oeconomica Jadertina, Vol. 4, No. 2, str. 33-52.

3. Bhimani, A., Horngren, C.T., Datar, S.M., Foster, G. (2018): Upravljačko računovodstvo i računovodstvo troškova, MATE d.o.o., Zagreb.

4. De Silva, P.B.M.G., Gunawardana, K., Silva, S.K.P.N. (2011): The Impact of Enterprise Resource Planning Systems on Management Accounting in 
Private Companies in Sri Lanka. Available at SSRN: https://ssrn.com/abstract=1742377.

5. Dwi May Adi Indra, L., Noorlailie, S., Isnalita, I. (2018): IMPACT OF ENTERPRISE RESOURCE PLANNING SYSTEMS ON THE ACCOUNTING INFORMATION RELEVANCE AND FIRM PERFORMANCE. Russian Journal of Agricultural and Socio-Economic Sciences (RJOAS), Vol. 8, No. 80, str. 81-87.

6. El-Sayed, H. (2006): ERPs and accountants' expertise: the construction of relevance. Journal of Enterprise Information Management, Vol. 19, No. 1, str. 83-96.

7. Garača, Ž. (2004): Poslovna informatika - od bita do globalizacije, Ekonomski fakultet, Sveučilište u Splitu, Split.

8. Gómez, A. (2017): Technology Brings Opportunities to Attract Young Talent. Preuzeto sa :https://www.ifac.org/global-knowledge-gateway /practice-management/discussion/technology-brings-opportunities-attract (29.05.2019)

9. Goumas, S., Charamis, D., Tabouratzi, E. (2018): Accounting Benefits of ERP Systems across the Different Manufacturing Industries of SMEs. Theoretical Economics Letters, Vol. 8, str. 1232-1246.

10. Granlund M. (2007): On the Interface between Management Accounting and Modern Information Technology - A literature review and some empirical evidence. Available at SSRN: https://ssrn.com/abstract=985074.

11. Granlund, M., Mouritsen, J. (2003): Special section on management control and new information technologies. European Accounting Review, Vol. 12, No. 1, str. 77-83.

12. Jack, L., Kholeif, A. (2008): Enterprise Resource Planning and a contest to limit the role of management accountants: A strong structuration perspective. Accounting Forum, Vol. 32, str. 30-45.

13. Jackling, B., Spraakman, G. (2008): The Impact of Enterprise Resource Planning Systems on Management Accounting: An Australian Study. The European Journal of Management and Public Policy, Vol. 5, No. 2, str. 6990.

14. Jean-Baptiste, R. (2009): Can Accountants Bring A Positive Contribution To ERP Implementation? International Management Review, Vol. 5, No. 2, str. 81-89.

15. Kallunki, J-P., Laitinen, E. K., Silvola, H. (2011): Impact of enterprise resource planning systems on management control systems and firm performance. International Journal of Accounting Information Systems, Vol. 12, No. 1, str. 20-39.

16. Kanellou, A., Spathis, C. (2011): Accounting Benefits and Satisfaction in an ERP Environment, $8^{\text {th }}$ International Conference on Enterprise Systems, Accounting and Logistics ( $8^{\text {th }}$ ICESAL 2011), 11-12 July 2011, Thassos Island, Greece. 
17. Kholeif, A. O. R., Abdel-Kader, M., Sherer, M. (2007): ERP customization failure: Institutionalized accounting practices, power relations and market forces. Journal of Accounting \& Organizational Change, Vol. 3, No. 3, str. 250-269.

18. Malinić, S., Todorović, M. (2012): How Does Management Accounting Change under the Influence of ERP? Economic Research - Ekonomska Istraživanja, Vol 25, No. 3, str. 722-751.

19. Maraghini, M. P. (2010): New Integrated Information Systems and Management Control Change in Small and Medium Enterprises. In P. Taticchi (Ed.), Business Performance Measurement and Management, str. 13-37.

20. Milanović Glavan, LJ. (2014): Procesna informacijska tehnologija u poduzećima Republike Hrvatske, Zbornik radova Veleučilišta u Šibeniku, No. 3-4, str. 35-48.

21. O’ Mahony, A., Doran, J. (2008): The Changing Role of Management Accountants; Evidence From the Implementation of ERP Systems in Large Organisations. International Journal of Business and Management, Vol. 3, No. 8, str. 109-115.

22. Panorama Consulting Solutions: CLASH OF THE TITANS 2017. Preuzeto sa: https://www.panorama-consulting.com/wp-content/uploads/ 2017/10/White-Paper-Clash-of-the-Titans-2017.pdf (09.03.2019.)

23. Pervan, I., Dropulić, I. (2019): The Impact of Integrated Information Systems on Management Accounting: Case of Croatia. Management: Journal of Contemporary Management Issues, Vol. 24, No. 1, str. 21-38.

24. Rikhardsson, P., Kræmmergaard, P. (2005): Identifying the effects of Enterprise System implementation and use: Examples from Denmark. Management Accounting Research Group Working Papers M-2005-07, University of Aarhus, Aarhus School of Business, Department of Business Studies.

25. Rom, A., Rohde, C. (2006): Enterprise resource planning systems, strategic enterprise management systems and management accounting: A Danish study. Journal of Enterprise Information Management, Vol. 19, No. 1, str. 50-66.

26. Sangster, A., Leech, S. A., Grabski, S. (2009): ERP implementations and their impact upon management accountants. Journal of Information Systems and Technology Management, Vol. 6, No. 2, str. 125-142.

27. Spathis, C. (2006): Enterprise systems implementation and accounting benefits. Journal of Enterprise Information Management, Vol. 19, No.1, str. 67-82.

28. Spathis, C., Ananiadis, J. (2005): Assessing the benefits of using an enterprise system in accounting information and management. Journal of Enterprise Information Management, Vol. 18, No. 2, str. 195-210.

29. Šimić, I. (2018): Utjecaj ERP sustava na poslovanje društva Dm-drogerie markt d.o.o., diplomski rad, Ekonomski fakultet, Sveučilište u Splitu. 
30. Šimunović, K., Šimunović, G., Havrlišan, S., Pezer, D., Svalina, I. (2013): Uloga ERP sustava u poslovnom procesu i edukaciji, Tehnički vjesnik, Vol. 20, No. 4, str. 711-719. 


\title{
Ivana Dropulić, Ph.D
}

Faculty of Economics, University of Split, Split, Croatia

ivana.dropulic@efst.hr

\section{THE IMPACT OF INTEGRATED INFORMATION SYSTEMS ON MANAGEMENT ACCOUNTING: A LITERATURE REVIEW}

Received: July 15, 2019

Accepted: November 21, 2019

\begin{abstract}
Based on a review of previous research of relationships between information technology (IT) and management accounting, it can be concluded that there is a certain gap in understanding this relationship. Since there is a lack of clearly identified changes in management accounting resulting from the influence of IT, the purpose of this research is to provide both an overview and an assessment of the impact of IT on management accounting in order to provide the basis for a better understanding of this relationship, both in the field of science and in practice.
\end{abstract}

The paper provides a comprehensive overview of the impact of IT on management accounting practices and the role and tasks of management accountants in the organisation over the past 15 years. According to the research findings, a it can be concluded that IT plays a significant role in management accounting practices, particularly in the area of internal reporting, planning and application of advanced management accounting techniques, as well as on the role and tasks of management accountants in the organisation. Management accountants perform routine tasks to a lesser extent and are more involved in the process of analysis, while outputs of management accounting are more precise, accurate and frequent under the influence of IT.

Keywords: information technology, enterprise resource planning systems (ERP), management accounting

JEL: M41, M49 